\title{
SIDESTREAM FILTRATION OF COOLING TOWER WATER
}

C. R. Schmitt

\section{UNION} CARBIDE

\section{OAK RIDGE Y-12 PLANT} OAK RIDGE, TENNESSEE 


\section{DISCLAIMER}

This report was prepared as an account of work sponsored by an agency of the United States Government. Neither the United States Government nor any agency Thereof, nor any of their employees, makes any warranty, express or implied, or assumes any legal liability or responsibility for the accuracy, completeness, or usefulness of any information, apparatus, product, or process disclosed, or represents that its use would not infringe privately owned rights. Reference herein to any specific commercial product, process, or service by trade name, trademark, manufacturer, or otherwise does not necessarily constitute or imply its endorsement, recommendation, or favoring by the United States Government or any agency thereof. The views and opinions of authors expressed herein do not necessarily state or reflect those of the United States Government or any agency thereof. 


\section{DISCLAIMER}

Portions of this document may be illegible in electronic image products. Images are produced from the best available original document. 
Reference to a company or product name does not imply approval or recommendation of the product by Union Carbide Corporation or the U.S. Atomic Energy Commission to the exclusion of others that may meet specifications.

\begin{tabular}{|c|}
\hline Printed in the United States of America. Available from \\
National Technical Information Service \\
U.S. Department of Commerce \\
5285 Port Royal Road, Springfield, Virginia 22151 \\
Price: Printed Copy $\$ 4.00 ;$ Microfiche $\$ 0.95$
\end{tabular}

This report was prepared as an account of work sponsored by the United States Government. Neither the United States nor the United States Atomic Energy Commission, nor any of their employees, nor any of their contractors, subcontractors, or their employees, makes any warranty, express or implied, or assumes any legal liability or responsibility for the accuracy, completeness or usefulness of any information, apparatus, product or process disclosed, or represents that its use would not infringe privately owned rights. 


\title{
SIDESTREAM FILTRATION OF COOLING TOWER WATER
}

\author{
C. R. Schmitt
}

Oak Ridge Y-12 Plant

P.O. Box Y, Oak Ridge, Tennessee 37830

Date Issued - June 29, 1973

Prepared for the U.S. Atomic Energy Commission

Under U.S. Government Contract W.7405eng.26

This report was prepared as an account of work sponsored by the United States Government. Neither the United States nor the United States Atomic Energy Commission, nor any of theis cimployooc, nnr any of makes any warranty, express or implied, or assumes any makes any warranty, expribility for the accuracy, completeness or usefulness of any infortllatiui, apparatuc, product or process disclosed, or represents that its use would not infringe privately owned rights. 


\begin{abstract}
Laboratory performance tests were conducted with a column of filter sand to evaluate the suitability of the sand grains ( 0.3 to $0.8 \mathrm{~mm}$ in diameter) for use in automatic and valveless sidestream filter installations for removing suspended solids from cooling-tower water systems.

Analytical studies were made on samples of cooling water and suspended solids from two 10-foot-diameter by 15-foot-high sidestream filter installations to identify the type and particle-size range of particulates being removed by the filters. Particle-size range of the removed suspended particulates was approximately 5 to 32 micrometers in diameter; and, after the first year of operation, the filters have continued to provide satisfactory and mainterance-free operation.
\end{abstract}




\section{CONTENTS}

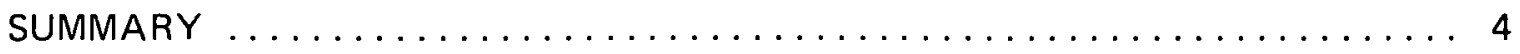

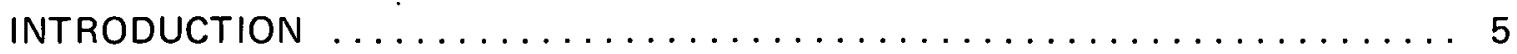

SIDESTREAM FILTRATION STUDY $\ldots \ldots \ldots \ldots \ldots \ldots \ldots \ldots \ldots \ldots \ldots$

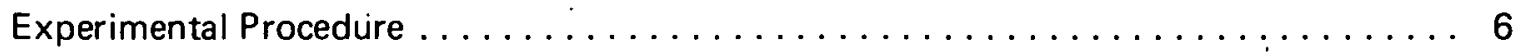

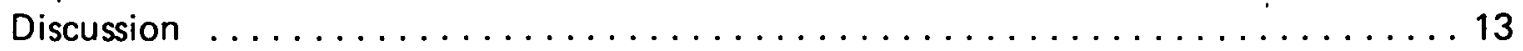

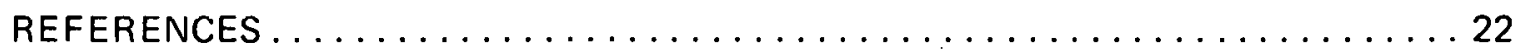




\section{SUMMARY}

Analytical characterization studies were made on samples of suspended solids taken from the cooling-tower water system located at the east end of the Oak Ridge Y-12 Plant (a) to identify the type and particle-size range of the solids that were causing flowmeter and sight-glass difficulties, and a rapid plugging of the cellulose cartridge filters. The solids were found to consist of a complex mixture of organic and inorganic constituents, including some angular fly-ash particles approximately 1 to 100 micrometers in diameter, some hollow fly-ash microspheres, filamentous algae, and microbial growths with many heterogeneous infusorians.

Laboratory tests were conducted with a column of filter sand and east-end-tower cooling water to evaluate the performance characteristics of the sand $(0.30-0.84 \mathrm{~mm}$ in diameter) for removing these finely divided suspended solids. This sand had been procured for planned use in automatic and valveless 10-foot-diameter by 15-foot-high sidestream filter installations. Using a 24-inch bed depth of sand, the column effluent turbidity ranged from 6 to 8 parts per million (ppm) silicon dioxide at operating flow rates of $2-3 \mathrm{gpm} / \mathrm{ft}^{2}$. After eight hours of continuous filtration using a feedwater to the column having a turbidity of 44 $\mathrm{ppm}$ silicon dioxide, the sand grains were back washed and the collected suspended matter was readily removed from the bed. The turbidity of the backwash water was $656 \mathrm{ppm}$ silicon dioxide.

After installing two 10-foot-diameter by 15 -foot-high automatic and valveless sidestream sand filters at the east and west-end locations in the Plant, analytical characterization data were obtained on the suspended solids removed from the blowdown waters of these filters. The suspended solids had an average particle diameter of 11 micrometers, ranging from 2 to 60 micrometers in diameter. The filters have provided satisfactory and maintenance-free operation after their first year of service.

(a) Operated by the Union Carbide Corporation's Nuclear Division for the US Atomic Energy Commission. 


\section{INTRODUCTION}

Filtration is used in the treatment of industrial water in order to remove suspended solids or to reduce the amount of turbidity. Sidestream filtration has shown many benefits in recirculating cooling tower water applications. In sidestream filtration, a small portion of the circulated water from a cooling tower, usually about two percent, is passed through a bed of sand, sand and gravel, or anthracite coal as a filter medium which removes organic matter, silt, and/or turbidity from the water.

The general objective of this type of filtration is to improve the quality of the circulated water so that satisfactory heat transfer may be achieved by reducing the amount of silting and fouling in heat exchangers and at low flow velocities in pipelines associated with the system. Such solids can also adsorb some of the water-soluble scale and corrosion-inhibiting compounds (eg, chromates and polyphosphates) that are added to the water. By removing suspended solids from the water system, a decrease in the cost of chemical treatment can also be realized because the loss of these adsorbed inhibitors on solids in the blowdown water is minimized.

Recently, the presence of finely divided suspended solids and sludge accumulations in the recirculating cooling water system of a building located at the east end of the Y-12 Plant caused considerable operational difficulties such as excessive plugging of small-diameter water lines used to cool high-temperature furnaces, obscuration of sight glasses and water flowmeters, and excessive plugging and replacement of cellulose filter cartridges. Laboratory tests were needed to determine the chemical nature of these suspended solids and to evaluate the suitability of a proprietary sand filter medium for an automatic, valveless, sidestream gravity filter in this cooling water system. 


\section{SIDESTREAM FILTRATION STUDY}

\section{EXPERIMENTAL PROCEDURE}

Analytical studies were made on samples of water and suspended solids taken from various locations in the east-end recirculating cooling water system to identify the chemical nature and general particle-size range of the sludge solids causing operational difficulties.

Photomicrographs (presented in Figures 1 through 4) showed the solids to consist of a complex mixture of organic and inorganic constituents, including some angular and spherical fly-ash particulates (Cenospheres), (1) and some filamentous algae, diatoms, and microbiological organisms and growths with many heterogeneous infusorians such as the paramecium. Complete identification of the numerous types of plant and animal species that were observer hy mirrnsconir. examination was beyond the scope of this study. Infrared spectra of the petroleum ether and chloroform soluble portions of the air-dried suspended solids obtained by laboratory filtration also showed the presence of some hydrocarbon oil and oil decomposition products.

Sieve analyses were made on a sample of sand obtained from the vendor of the automatic, valveless gravity filter which was to be installed in the cooling-tower water system. Results, as summarized in Table 1 and Figure 5, showed that approximately 80 percent of the grains had a diameter of $0.3-0.8 \mathrm{~mm}(-20+50$ mesh) and a calculated uniformity coefficient of 1.66. The term "uniformity coefficient" is frequently used in characterizing a sand to be used for water filtration purposes. By definition, "uniformity coefficient" is the ratio of the size of the sand grain which has 60 percent of the sample finer than itself to the size which has 10 percent finer than itself. (2) As shown in Figure 5, the ratio of the 60 percent to the 10 percent mesh diameter sizes is 0.78 to $0.47 \mathrm{~mm}$, or a sand uniformity coefficient of 1.66. Photomicrographs showing the particle shape of various sieve fractions of the vendor's sand grains are provided in Figure $\ddot{6}$.

Tạle 1

SIEVE ANALYSIS OF SAND FOR VALVELESS GRAVITY FILTER

\begin{tabular}{|c|c|c|c|c|c|}
\hline \multirow[b]{3}{*}{$\begin{array}{c}\text { US } \\
\text { Sieve } \\
\text { Number }\end{array}$} & \multirow[b]{3}{*}{$\begin{array}{l}\text { Diallieter } \\
\text { of Opening } \\
\text { (mm) }\end{array}$} & \multicolumn{2}{|c|}{ Eand (gms) } & \multirow{2}{*}{\multicolumn{2}{|c|}{ Percent }} \\
\hline & & \multirow[b]{2}{*}{$\begin{array}{l}\text { Retained } \\
\text { on Sieve }\end{array}$} & \multirow{2}{*}{$\begin{array}{l}\text { Cumulative } \\
\text { Paselng } \\
\text { Mesh Size } \\
\text { Shown }\end{array}$} & & \\
\hline & & & & $\begin{array}{l}\text { Retained } \\
\text { UII 3ieve }\end{array}$ & $\begin{array}{c}\text { Fincr Than } \\
\text { Mesh Size } \\
\text { Ehown }\end{array}$ \\
\hline 10 & 2.000 & 0.3 & 747.4 & 0.0004 & 99.96 \\
\hline 20 & 0.841 & 142.5 & 604.9 & 19.1 & 80.9 \\
\hline 30 & 0.595 & S2'1.0̄ & 183.9 & 56.3 & 21.6 \\
\hline 40 & 0.420 & 147.9 & 36.0 & 19.8 & 4.8 \\
\hline 50 & 0.297 & 32.6 & 3.4 & 4.4 & 0.5 \\
\hline 200 & 0.074 & 3.4 & 0 & 0.5 & 0 \\
\hline
\end{tabular}

Laboratory filtration tests were conducted on a column of the filter sand using east-end cooling-tower water containing suspended particulates to evaluate the performance characteristics of the sand for removing the finely divided suspended material. A diagrammatic representation of the laboratory sand filtration apparatus used is given in 

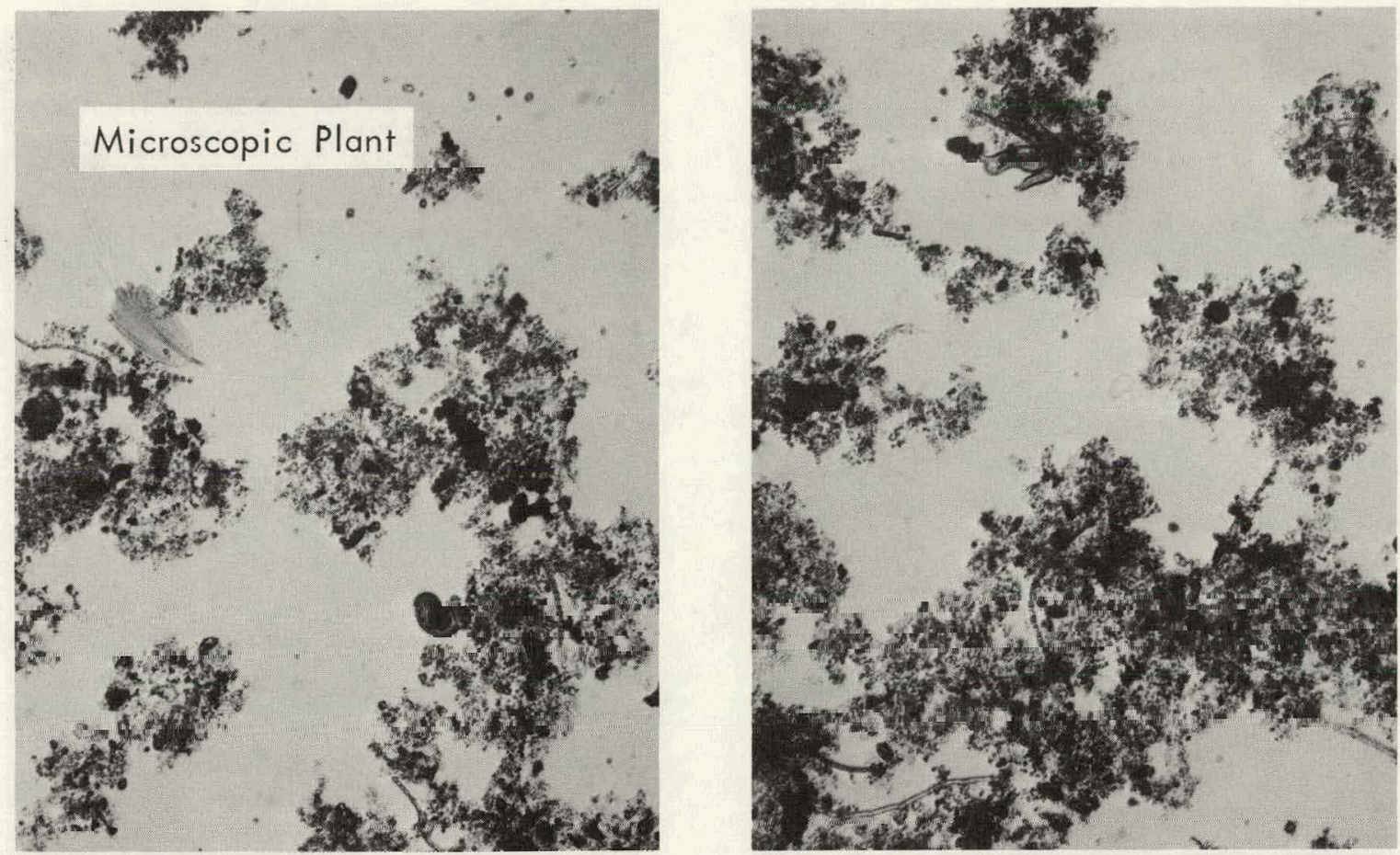

$100 x$

$100 x$
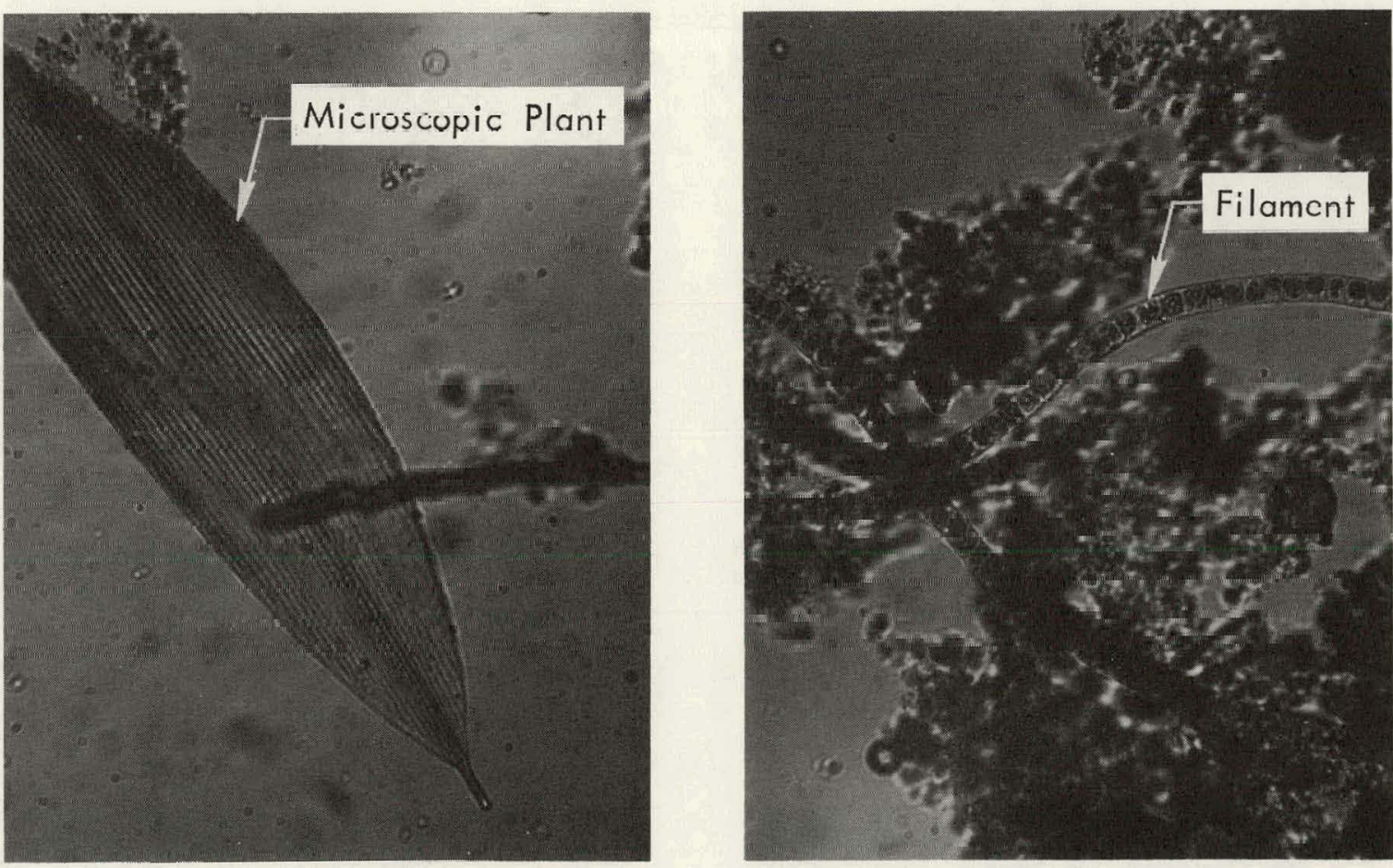

$400 x$

$400 x$ 

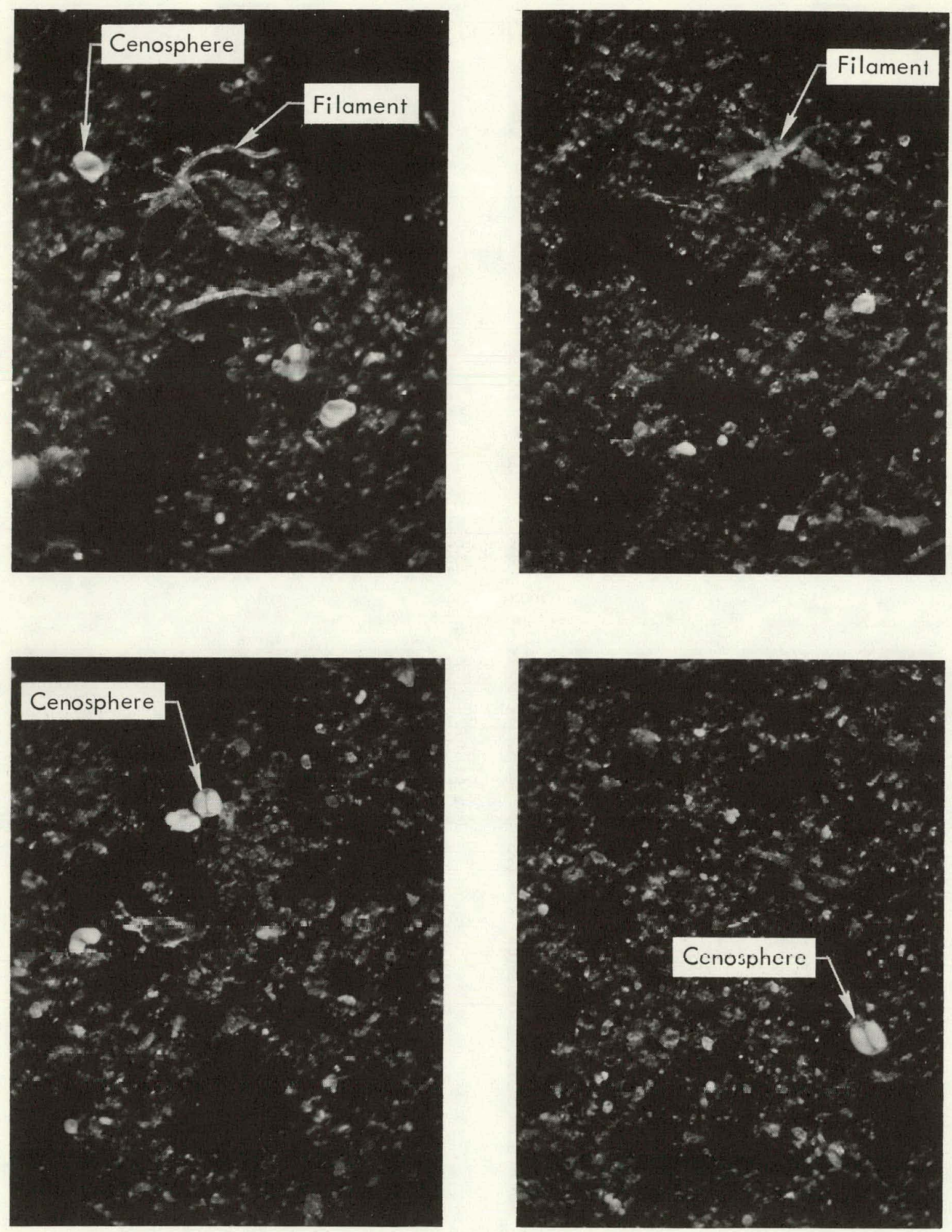

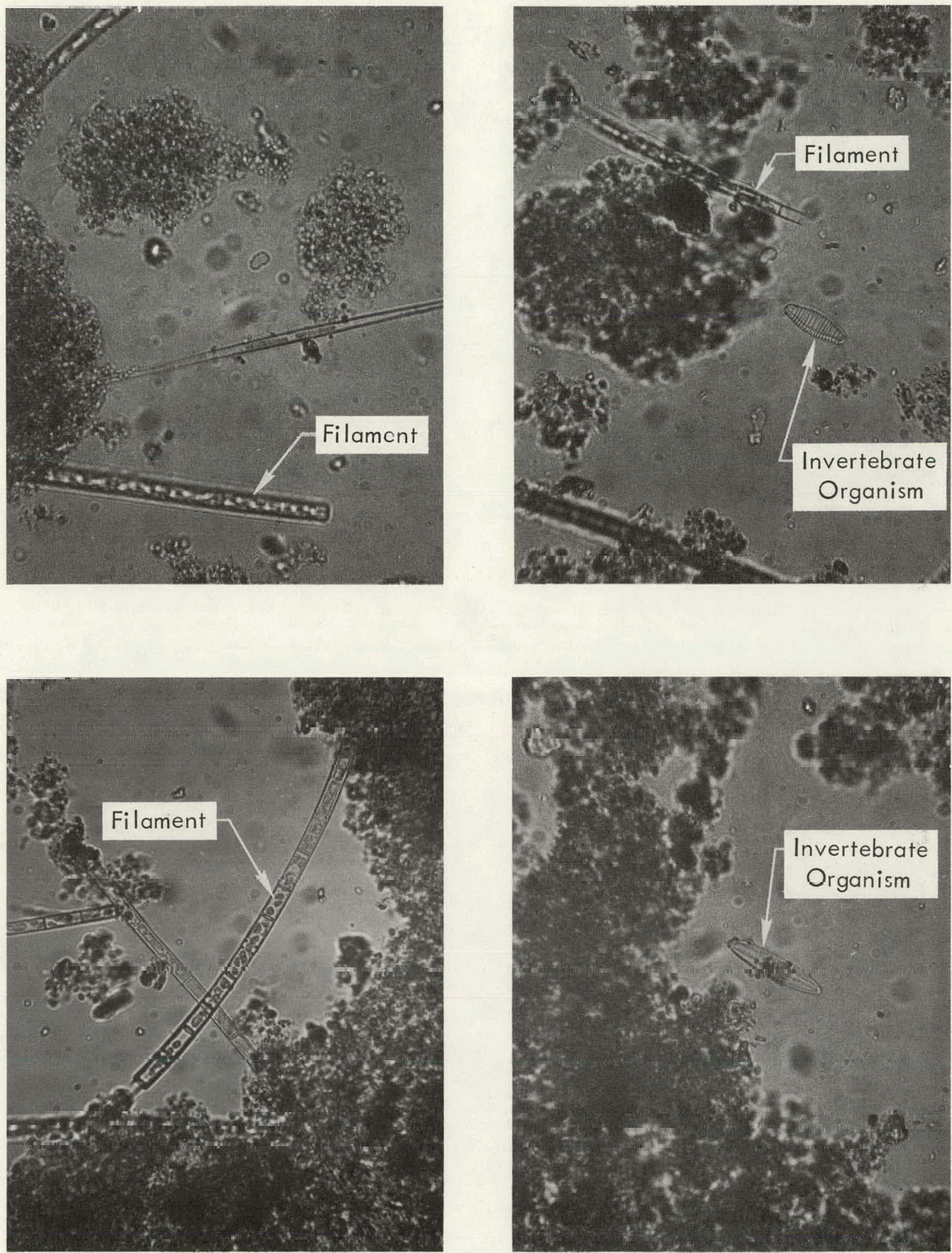

Figure 3. PHOTOMICROGRAPHS OF COOLING-TOWER BASIN SOLIDS. (Transmitted Light; 400X)

138525 

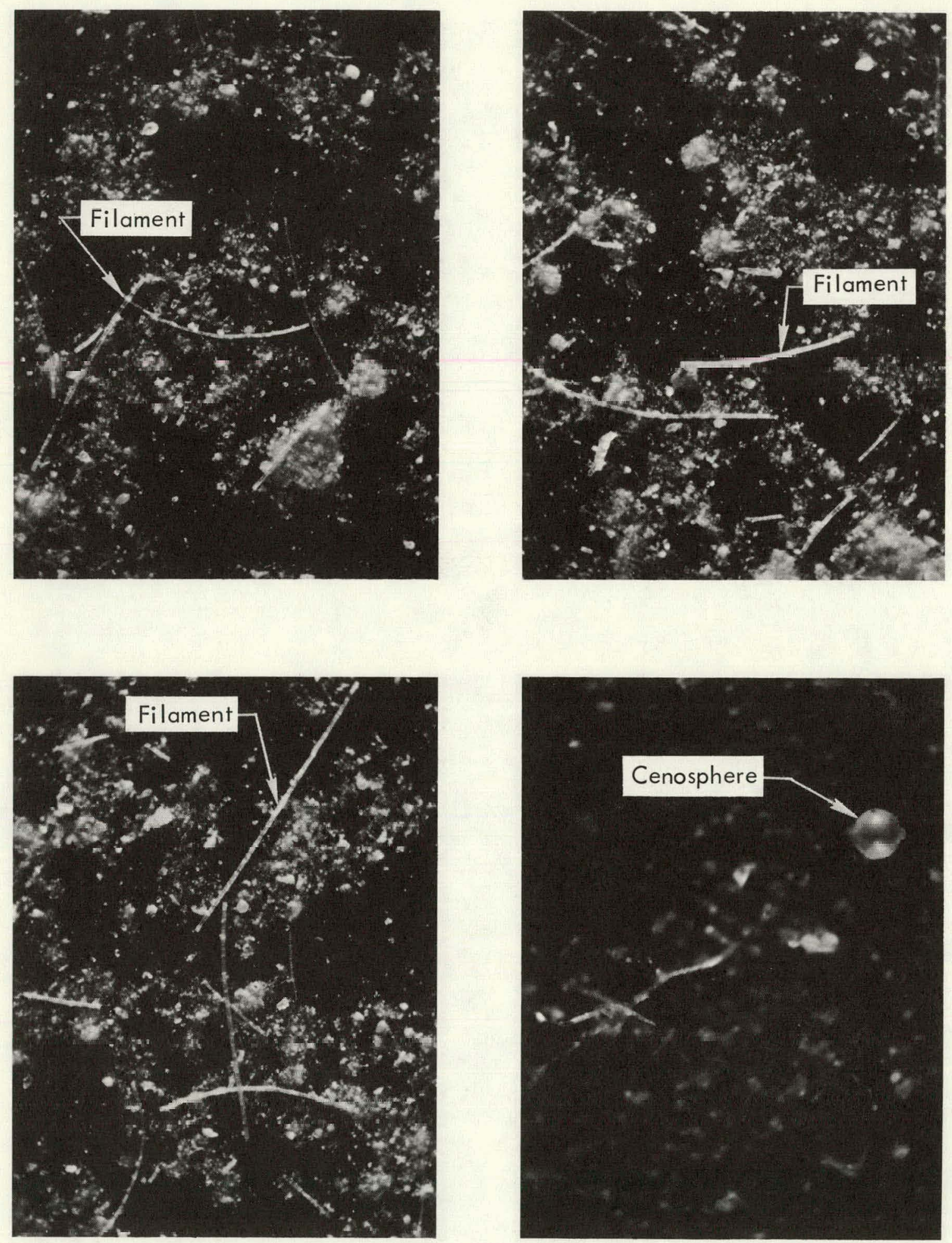

Figure 4. PHOTOMICROGRAPHS OF COOLING-TOWER BASIN SOLIDS. (Reflected Light; 100X)

138523 
Figure 7. Using a 24-inch bed depth of sand, the effluent turbidity from the sand column ranged from $6-8 \mathrm{ppm}$ silicon dioxide, using water flow rates of $2-3$ $\mathrm{gpm} / \mathrm{ft}^{2}$. The turbidity of the influent water to the column was $44 \mathrm{ppm}$ silicon dioxide. After eight hours of continuous filtration, the sand grains were backwashed with clear water and the suspended matter collected by the sand grains was easily removed from the bed. The turbidity of the backwash water was $656 \mathrm{ppm}$ silicon dioxide. Photomicrographs showing the type of organic and inorganic suspended solids removed from the sand grains after backwashing are presented in Figure 8.

Figure 9 provides a view of a typical

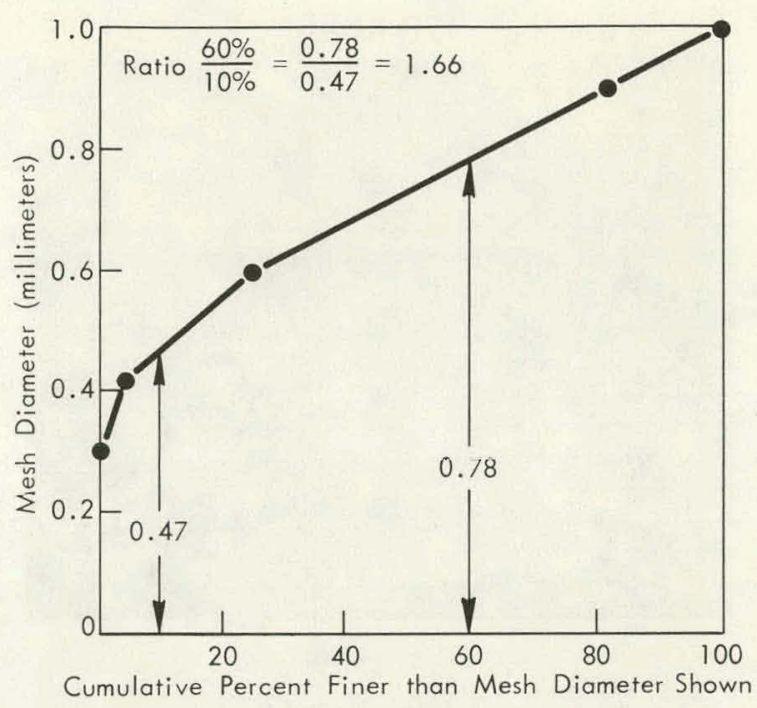

Figure 5. SIEVE ANALYSIS OF SAND FOR THE VALVELESS GRAVITY FILTER. cellulose filter cartridge installation in an east-end building using cooling-tower water that had become plugged with solid particulates after only eight hours of operation. A photograph of the plugged internal cellulose filter element showing the degree of fineness of particles that had accumulated in the pores of the filter cartridge is given in Figure 10.

Photographs showing the cooling tower structures of the east-end recirculating water system are presented in Figures 11 and 12. The cooling tower of Figure 11 is an older unit; the cooling tower of Figure 12 was added to the system as an auxiliary cooling unit during 1965. Both towers are located directly west of the Y-12 Steam Plant and contain open water basins beneath the wooden superstructures. Thus, since the wind direction at the Plant is prevailing westerly, some accumulations of fly-ash particles at these towers could easily occur.

A proprietary slimicide treatment consisting of 33.75 percent sodium pentachlorophenate and 8.5 percent sodium trichlorophenate has been in effect for the past seven years to control microbiological growths. However, treatment dosages may need to be increased to minimize filter-plugging difficulties of microbial origin.

It has been demonstrated in these laboratory tests that the particle-size range of the sand proposed for the 10-foot-diameter valveless, gravity, sidestream filter unit was effective in removing a considerable amount of a finely divided suspended matter from the recirculating cooling tower water. In free-surface, rapid sand filtration, water is passed by gravity downward through the sand at high velocity, usually at rates ranging from 2 to 3 $\mathrm{gpm} / \mathrm{ft}^{2}$. (2) Using these same flow rates in the laboratory sand column, the effluent water turbidity ranged from 6 to $8 \mathrm{ppm}$ silicon dioxide, showing that most, but not all, of the finely divided solids and turbidity of the influent water (44 $\mathrm{ppm} \mathrm{SiO}_{2}$ ) had been removed. It was also determined that when the influent water flow rate was increased to $15 \mathrm{gpm} / \mathrm{ft}^{2}$, the column effluent turbidity had increased to $13 \mathrm{ppm}$ silicon dioxide. After operating the sand column continuously for seven hours, the sand grains became plugged with collected 

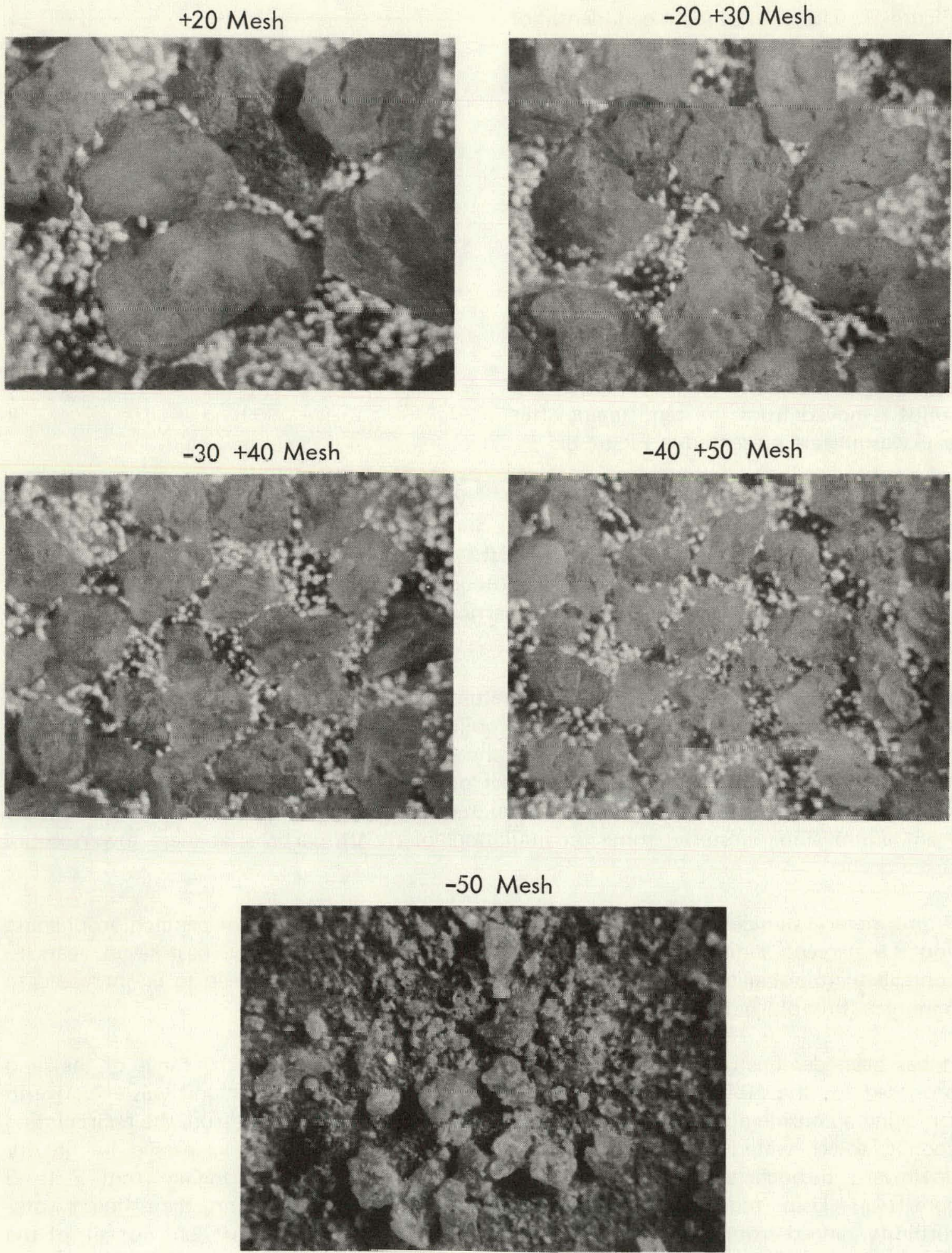

Figure 6. PHOTOMICROGRAPHS OF THE SIDESTREAM FILTER SAND GRAINS. 


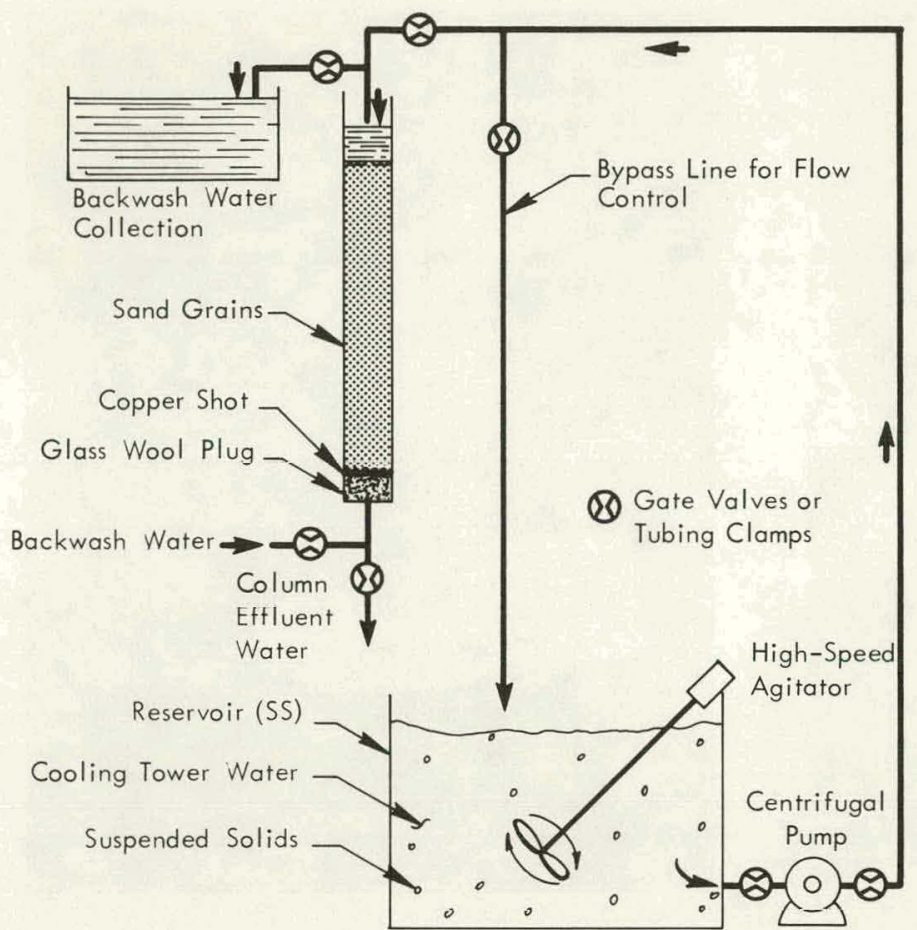

Figure 7. LABORATORY SAND FILTRATION SYSTEM FOR THE COOLING-TOWER WATER TEST. filter bed collects dirt and the head loss increases, the water level rises slowly in the inlet pipe and in the backwash pipe. Just before the water passes over the downward section of the backwash pipe, a self-actuated primer system evacuates air from the backwash pipe. This action pulls water rapidly over the pipe so that a large volume of water flows down the backwash pipe and starts the siphoning action that backwashes the filter. After backwashing, the filtering cycle is automatically repeated.

Samples of the backwash water were obtained from the 10-foot-diameter east and west-end automatic sidestream filters in order to characterize the suspended solid particulates picked up by the sand grains from the two cooling-tower water systems. Spark-source mass spectrographic analyses of the suspended solids particulates are summarized in Tables 2 and 3; a graph of the particle-size distribution data is provided in Figure 15.

\section{DISCUSSION}

The two 10-foot-diameter by 15 -foot-high automatic, valveless, gravity, sidestream filters recently installed at the east and west ends of the $\mathrm{Y}$ - 12 Plant represent a most recent design innovation in the water treatment field. Each filter is suitable for filtering 150 gallons of cooling water per minute. The filters do not have any pumps, valves, gauges, or manual or electrical controls. Details regarding the engineering, operation, and maintenance features of the filter have been summarized elsewhere. (3)

Fundamentally, as outlined in Figure 14, the sidestream filter consists of a three-compartment open tank, a filter-sand-bed section, and a collection section. Cooling 

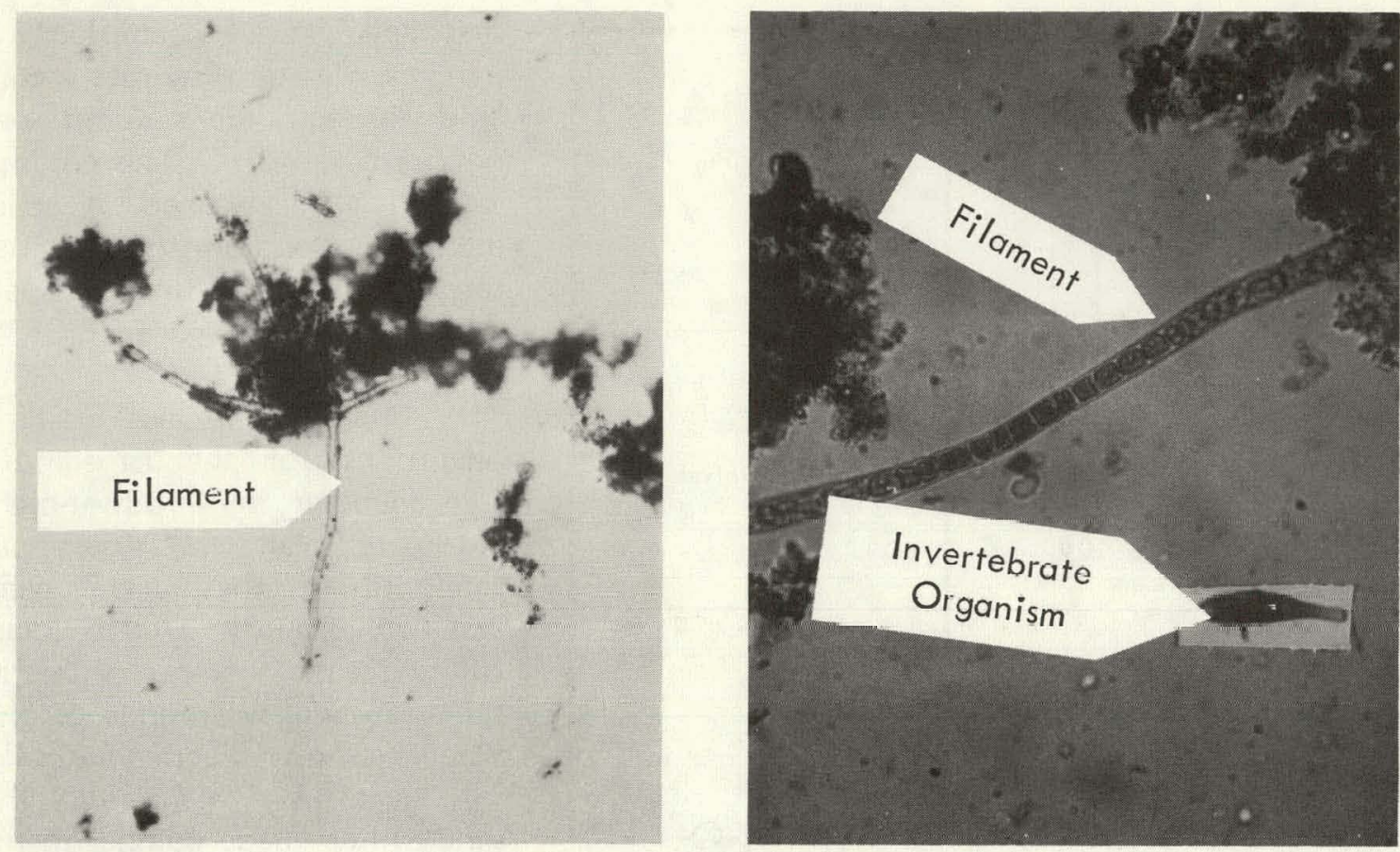

$100 x$

$400 x$

Transmitted Light
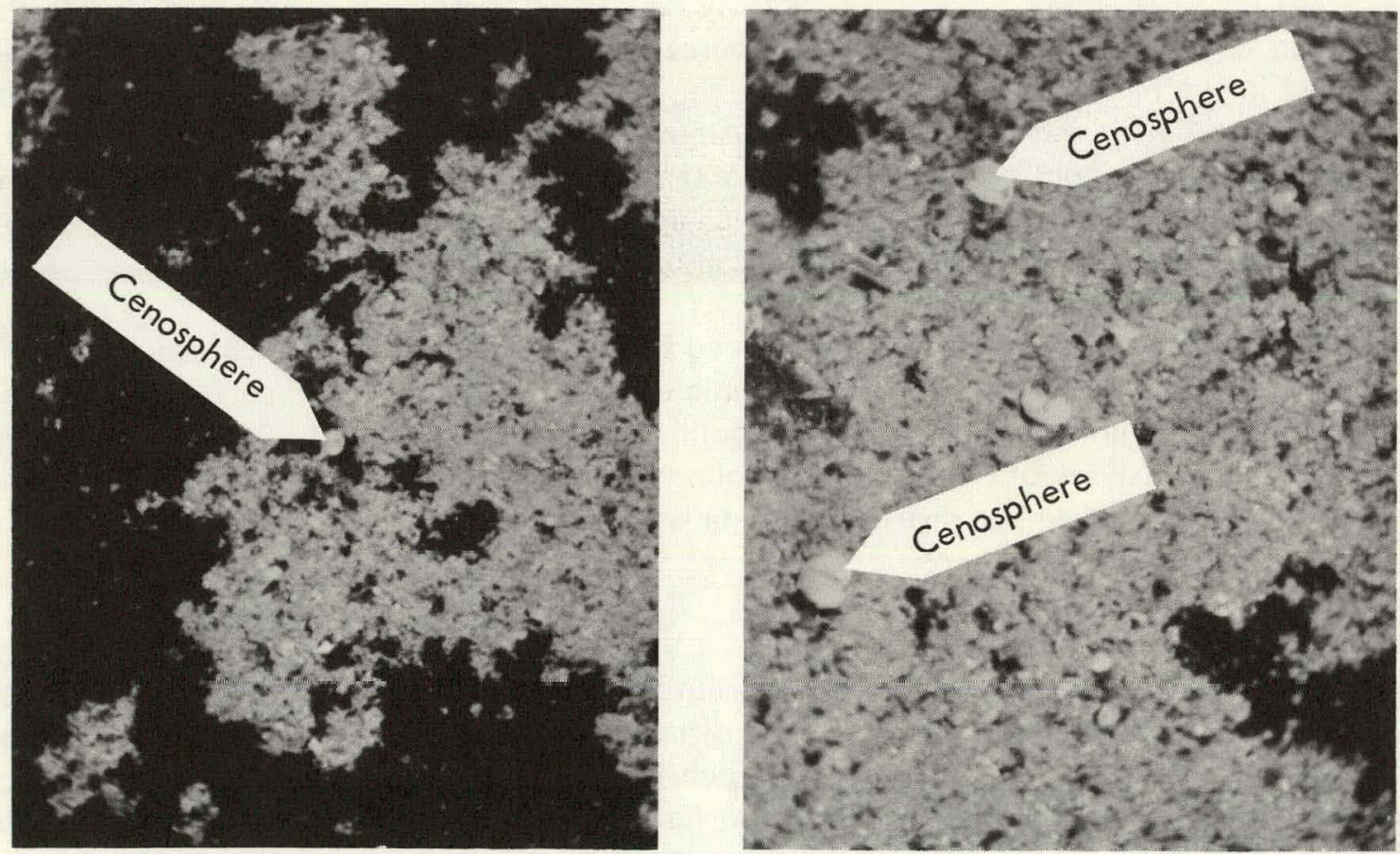

$100 x$

$400 x$

Reflected Light

Figure 8. PHOTOMICROGRAPHS OF FILTER SAND BACKWASH SOLIDS. 


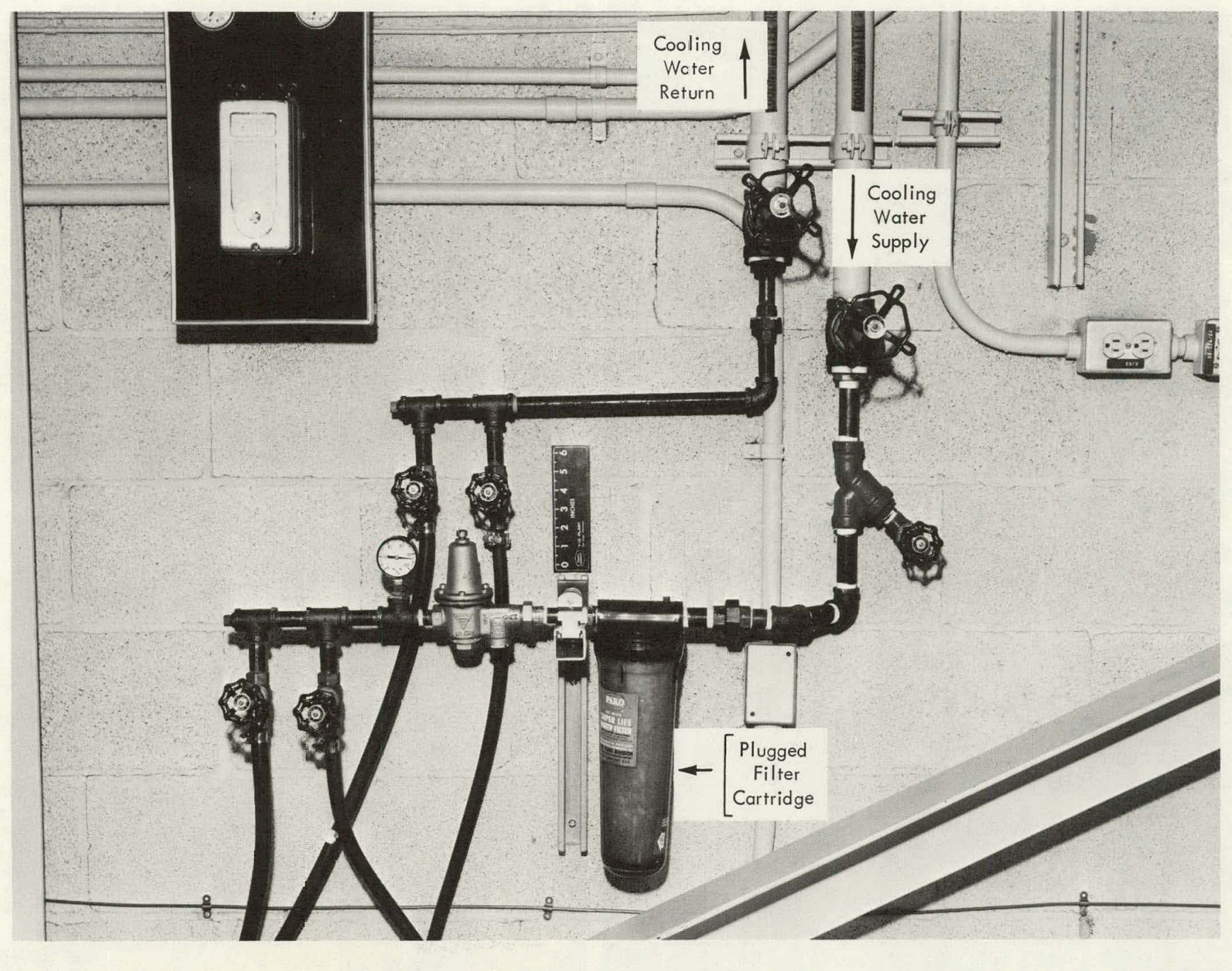

Figure 9. PLUGGED CELLULOSE FILTER INSTALLATION FROM THE EAST-END COOLING-WATER SYSTEM.

137475 


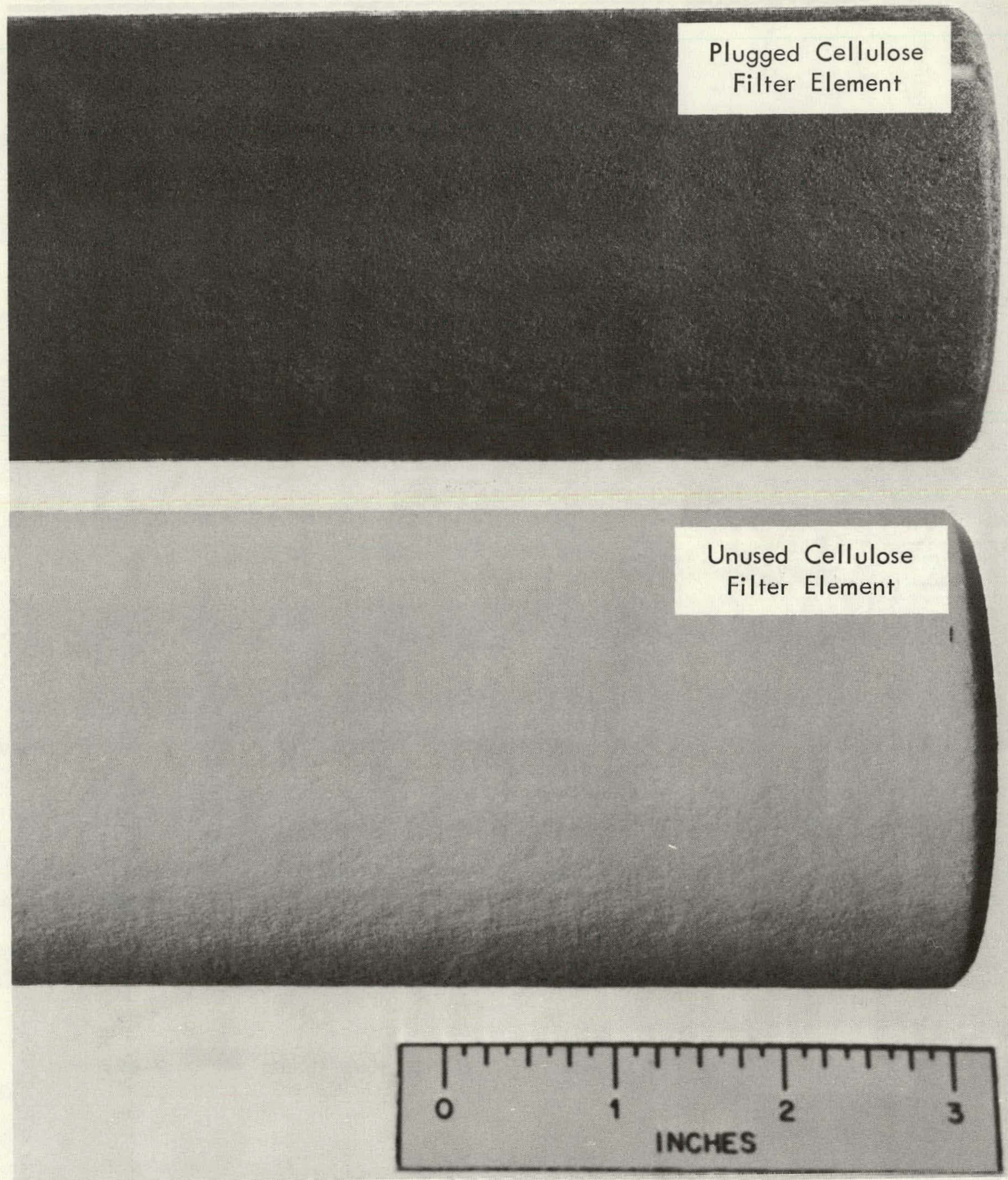

137473

Figure 10. PLugged CELlulose FILTER ELEMENT FROM THE EAST-END COOLING-WATER SYSTEM SHOWING THE DEGREE OF FINENESS OF THE PARTICULATES. (An Unused Element is Shown for Comparison)

water flows at a constant rate into the chamber immediately above the sand and then passes downward through the sand and the strainers located in the false bottom. From this lowest chamber the water passes upward through ducts to the backwash storage chamber and serves as supply water for the next backwash. As the run progresses, the head loss increases across 


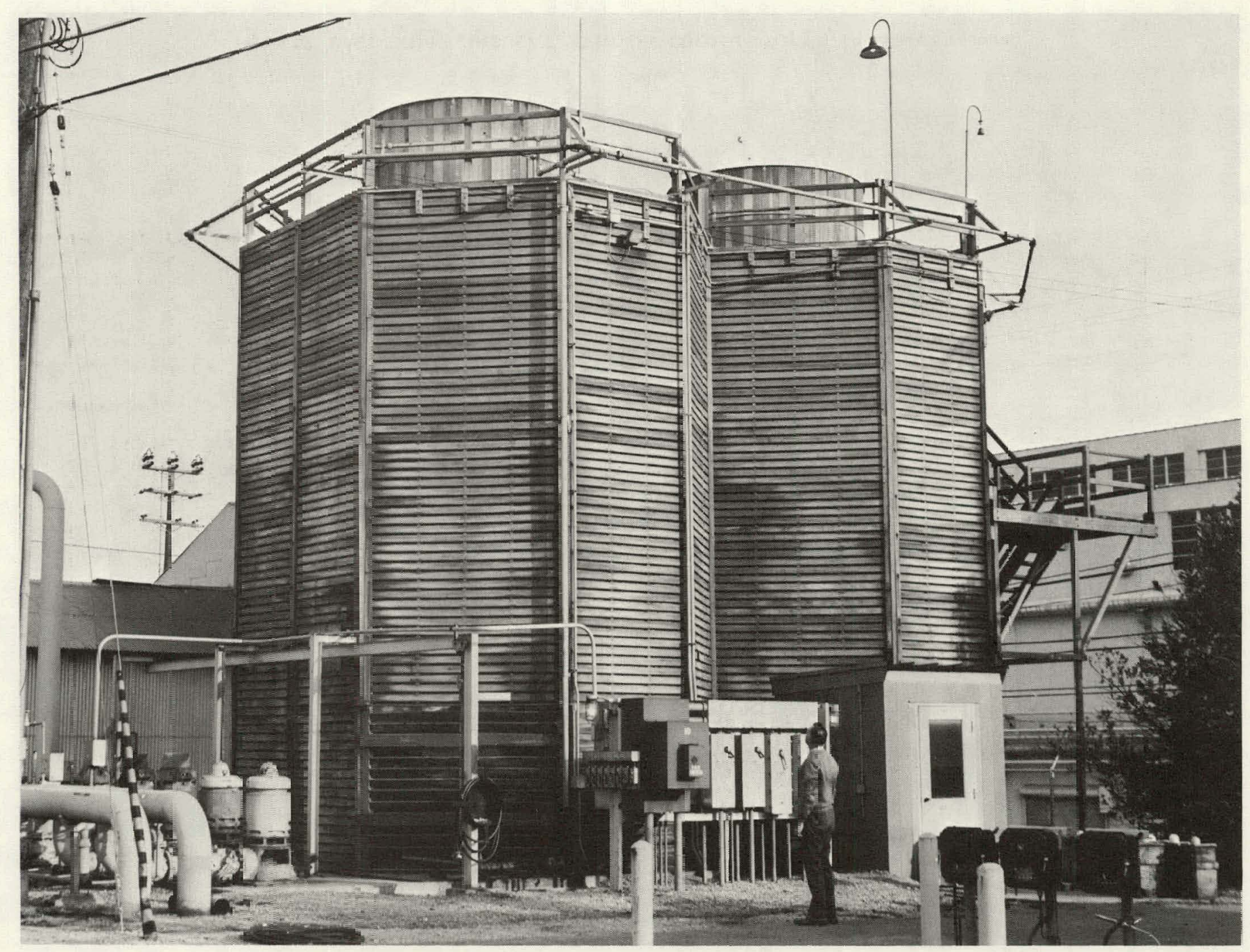

Figure 11. E.MST-END RECIRCULATING WATER COOL NG TOWER. (Original Structure)

137474 


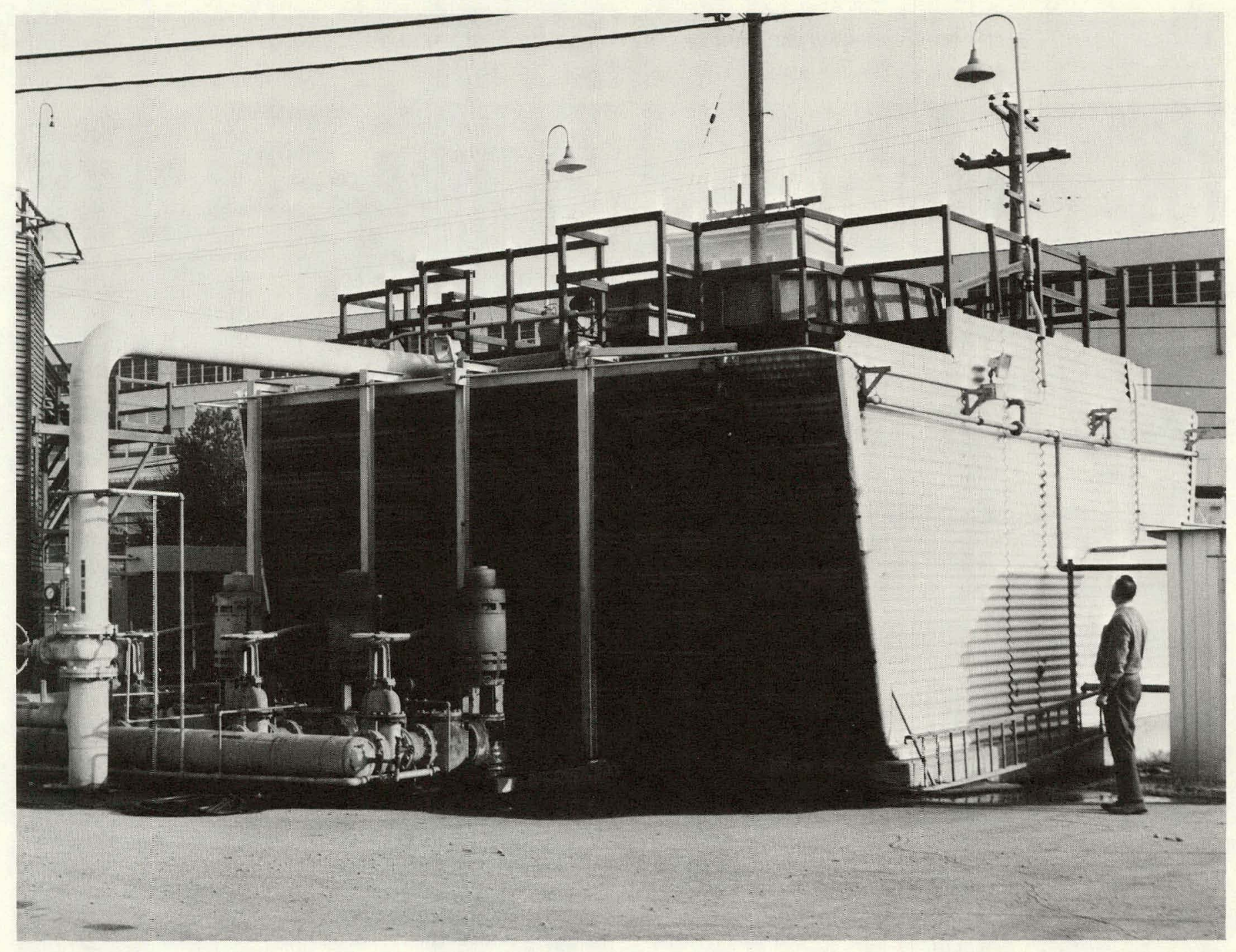

Figure 12. EAST-END RECIRCULATING WATER COOLING TOWER. (Auxiliary Structure)

137476 
the sand bed. This change causes rising water levels in the inlet pipe and in the backwash pipe which are proportional to the loss of head in the filter. When the loss in head reaches a predetermined figure for the end of the filter service run, the rinsing water runs over into the downward section of the backwash pipe and initiates the backwashing operation.

When the water level in the water storage tank drops below the end of the siphon breaker, air enters and stops the backwash. The How in the filter bed then reverses and

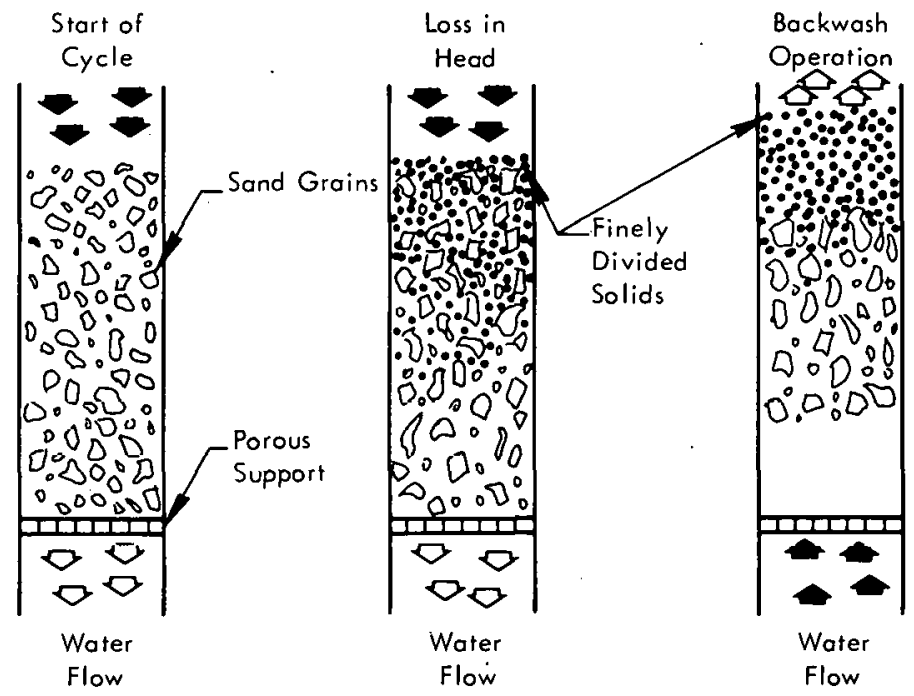

Figure 13. REPRESENTATION3 OF THE BAND FILTRATION OPERATIONS. influent water again flows down through the filter, automatically rinsing the bed. At this point, the service cycle starts over again with the rinse water rising to the storage tank to provide backwash water for the next cycle.

The current design criteria for sidestream filters of this type usually specify a flow rate of approximately two percent of the circulated water in the system. It is expected that the use of sidestream filters for the removal of suspended solids from the cooling water systems will improve the quality of the circulated water so that improved heat transfer may be achieved in the process cooling units. Accumulations and deposition of such solids can foul or scale
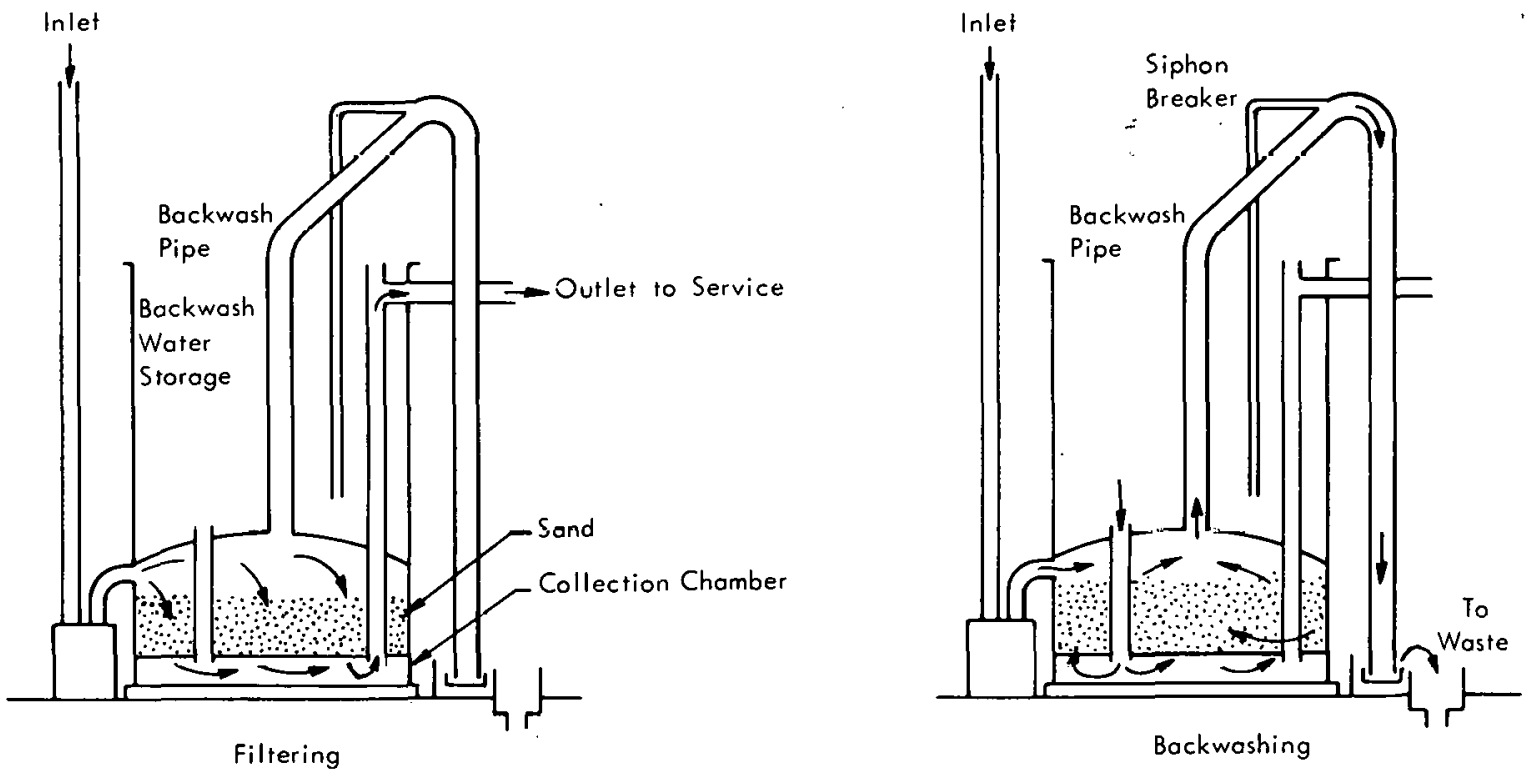

Figure 14. FILTERING AND BACKWASHING CYCLES OF A COMMERCIAL, AUTOMATIC, VALVELESS, GRAVITY FILTRATION SYSTEM. 
Table 2

SPARK-SOURCE MASS SPECTROGRAPHIC ANALYSES OF SLUDGE SOLIDS REMOVED FROM THE BOTTOM OF THE EAST-END SIDESTREAM FILTER

\begin{tabular}{|c|c|c|c|c|c|c|}
\hline Element & $\begin{array}{c}\text { Sample } \\
1(1) \\
(\%)\end{array}$ & & $\begin{array}{l}\text { Sample } \\
2^{(2)} \\
(\%)\end{array}$ & Element & $\begin{array}{c}\text { Sample } \\
1(1) \\
(\%)\end{array}$ & $\begin{array}{l}\text { Sample } \\
2^{(2)} \\
(\%)\end{array}$ \\
\hline$A_{\mathfrak{j}}$ & Support (3) & & Support (3) & Mo & 0.005 & 0.0025 \\
\hline si & 1. & & 9.0 & $\mathrm{Na}$ & نُ.3́s & U.35 \\
\hline As & 0.03 & & 0.015 & $\mathrm{INb}$ & 0.001 & 0.001 \\
\hline Au & $<0.0002$ & & $<0.0002$ & $\mathrm{Nd}$ & 0.007 & 0.007 \\
\hline B & 0.0050 & & 0.0050 & $\mathrm{NI}$ & |1 (1114) & $n \cap 15$ \\
\hline $\mathrm{Ba}$ & 0.25 & : & 0.20 & Os & $<0.0002$ & $<0.0002$ \\
\hline $\mathrm{Be}$ & 0.00004 & & 0.00005 & $\mathbf{P}$ & 0.05 & 0.90 \\
\hline $\mathrm{Bi}$ & $<0.0001$ & 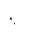 & $<0.0001$ & $\mathrm{~Pb}$ & 0.050 & 0.045 \\
\hline $\mathrm{Br}$ & 0.0020 & & 0.0006 & Pd & $<0.0006$ & $<0.0006$ \\
\hline $\mathrm{Ca}$ & Matrix & & Matrix & $\operatorname{Pr}$ & 0.001 & 0.0003 \\
\hline $\mathrm{Cd}$ & 0.0005 & & $<0.0002$ & $\mathrm{Pt}_{\mathrm{t}}$ & $<0.0002$ & $<0.0002$ \\
\hline $\mathrm{Ce}$ & 0.01 & & 0.009 & $\mathrm{Rb}$ & 0.0040 & 0.0040 \\
\hline $\mathrm{Cl}$ & 0.30 & $\therefore$ & 0.55 & $\mathrm{Re}$ & $<0.0002$ & $<0.0002$ \\
\hline Co & 0.0007 & & 0.0010 & $\mathrm{Rh}$ & $<0.0001$ & $<0.0001$ \\
\hline $\mathrm{Cr}$ & 1.95 & & 1.35 & Ru & $<0.0005$ & $<0.0001$ \\
\hline $\mathrm{Cs}$ & $<0.0002$ & & 0.0002 & s & 0.45 & 0.15 \\
\hline $\mathrm{Cu}$ & 0.20 & & 0.15 & $\mathrm{Sb}$ & 0.0010 & 0.0010 \\
\hline Dy & $<0.0007$ & ! & $<0.0002$ & sc & 0.002 & 0.0008 \\
\hline $\mathrm{Er}$ & $<0.0006$ & & $<0.0002$ & se & $<0.0002$ & $<0.0006$ \\
\hline Eu & $<0.0004$ & & $<0.0005$ & $\mathrm{Si}$ & 24.8 & 28.2 \\
\hline $\mathrm{F}$ & 0.025 & & 0.0080 & $\mathrm{Sm}$ & 0.0007 & $<0.001$ \\
\hline Fo & 10.6 & & 9.3 & $S_{11}$ & 0.0020 & 0.0010 \\
\hline $\mathrm{Ga}$ & 0.0007 & & 0.0006 & $\mathrm{Sr}$ & 0.065 & 0.060 \\
\hline Gd & $<0.001$ & & $<0.001$ & $\mathrm{Ta}$ & $<0.0007$ & $<0.0007$ \\
\hline $\mathrm{Ge}$ & 0.0008 & & 0.0020 & $\mathrm{~Tb}$ & $<0.0002$ & $<0.0002$ \\
\hline $\mathrm{Hf}$ & $<0.0008$ & & $<0.0003$ & $\mathrm{Te}$ & 0.0002 & 0.0002 \\
\hline $\mathrm{Hg}$ & $<0.0003$ & & $<0.0003$ & Th & 0.004 & 0.0010 \\
\hline Ho & $<0.0002$ & & $<0.0002$ & $T i$ & 0.80 & 0.75 \\
\hline 1 & 0.0020 & & 0.0002 & $\mathrm{TI}$ & $<0.0002$ & $<0.0003$ \\
\hline $\ln$ & $<0.0001$ & & $<0.0001$ & $T m$ & $<0.0002$ & $<0.0002$ \\
\hline Ir & $<0.0001$ & & $<0.0002$ & 11 & 0.016 & 0.015 \\
\hline$K$ & Matrix & & Matrix & $v$ & 0.003 & $0.0 n .3 n$ \\
\hline La & 0.006 & & 0.003 & w & 0.0020 & 0.0007 \\
\hline Lu & $<0.0002$ & & $<0.0002$ & $Y$. & 0.002 & 0.0005 \\
\hline Ma & 0.45 & & 0.45 & $Y_{b}$ & $<0,0007$ & $<0.0002$ \\
\hline \multirow[t]{2}{*}{$M n$} & 0.07 & & 0.03 & $\mathrm{Zn}$ & 0.15 & 0.15 \\
\hline & & & & $\mathrm{zr}$ & 0.01 & 0.01 \\
\hline
\end{tabular}

(1) Sludge solids were filtered and oven dried at $80^{\circ} \mathrm{C}$ prior to analysis.

(2) Sludge solids were filtered, washed with distilled water, and oven dried at $80^{\circ} \mathrm{C}$ prior to analysis. (.3) Ádder rnndur:tor.
Table 3

SPARK-SOURCE MASS SPECTROGRAPHIC ANALYSES OF SLUDGE SOLIDS REMOVED FROM THE BOTTOM OF THE WEST-END SIDESTREAM FILTER.

\begin{tabular}{|c|c|c|c|c|c|}
\hline & $\begin{array}{c}\text { Sample } \\
1(1)\end{array}$ & $\begin{array}{c}\text { Sample } \\
2^{(2)} \\
(\%)\end{array}$ & Element & $\begin{array}{c}\text { Sample } \\
1(1)\end{array}$ & $\begin{array}{c}\text { Sample } \\
2^{(2)} \\
(\%)\end{array}$ \\
\hline Element & (\%) & (\%) & Element & (\%) & \\
\hline $\mathrm{Ag}$ & 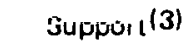 & Support (3) & Mo & < ก חก! & ถ.กกกร \\
\hline Ai & 1.21 & 1.45 & $\mathrm{Na}$ & 0.006 & n.35 \\
\hline As & 0.02 & 0.03 & $\mathrm{Nb}$ & $<0.001$ & 0.001 \\
\hline Au & $<0.0005$ & $<0.0002$ & $\mathrm{Nd}$ & 0.040 & 0.007 \\
\hline B & 0.0060 & 0.0050 & $\mathrm{NI}$ & ט.ง\% & 0.0090 \\
\hline Ba & 0.63 & 0.25 & Os & $<0.0005$ & $<0.0002$ \\
\hline $\mathrm{Be}$ & 0.0050 & 0.00004 & $\mathrm{P}$ & 1.90 & 0.95 \\
\hline $\mathrm{Bi}$ & $<0.0002$ & $<0.0001$ & $\mathrm{~Pb}$ & 0.12 & 0.05 \\
\hline $\mathrm{Br}$ & 0.009 & 0.0020 & $\mathrm{Pd}$ & $<0.001$ & $<0.0006$ \\
\hline $\mathrm{Ca}$ & 17.9 & Matrix & $\mathrm{Pr}$ & 0.005 & 0.001 \\
\hline $\mathrm{Cd}$ & $<0.001$ & 0.0005 & $P t$ & $<0.0005$ & $=0.0002$ \\
\hline $\mathrm{Ce}$ & 0.12 & 0.010 & $\mathrm{Rb}$ & 0.06 & 0.0040 \\
\hline $\mathrm{Cl}$ & 0.25 & 0.30 & $\mathrm{Re}$ & $<0.0005$ & $<0.0002$ \\
\hline $\mathrm{Co}$ & 0.02 & 0.0007 & $\mathrm{Rh}$ & $<0.0001$ & $<0.0001$ \\
\hline $\mathrm{Cr}$ & 5.1 & 1.95 & Ru & $<0.001$ & $<0.0005$ \\
\hline Cs & $<0.0005$ & $<0.0002$ & $s$ & 0.51 & 0.45 \\
\hline $\mathrm{Cu}$ & 0.12 & 0.20 & $\mathrm{Sb}$ & $<0.001$ & ח חฺ! \\
\hline نy & 0.0025 & $<0.0007$ & Sc & 0.0007 & 0.002 \\
\hline $\mathrm{Er}$ & $<0.0005$ & $<0.0006$ & $\mathrm{Se}$ & 0.0005 & $<0.0002$ \\
\hline Eu & 0.001 & $<0.0004$ & $\mathrm{Si}$ & 26.1 & 24.8 \\
\hline$F$ & 0.006 & 0.025 & $\mathrm{Sm}$ & 0.000 & 0.0007 \\
\hline Fe & 8.9 & 10.6 & Ŝn & 0.0040 & .0 .0020 \\
\hline Ga & 0.010 & 0.0007 & $\mathrm{Sr}$ & 0.19 & 0.065 \\
\hline Gd & 0.004 & $<0.001$ & $\mathrm{Ta}$ & $<0.006$ & $<0.0007$ \\
\hline $\mathrm{Ge}$ & 0.0006 & 0.0008 & $\mathrm{~Tb}$ & $<0.0001$ & $<0.0002$ \\
\hline $\mathrm{Hf}$ & $<0.0005$ & $<0.0008$ & $\mathrm{Te}$ & $<0.001$ & 0.0002 \\
\hline $\mathrm{Hg}$ & $<0.0005$ & $<0.0003$ & Th & 0.025 & 0.004 \\
\hline Ho & 0.0002 & $<0.0002$ & $T i$ & 2.5 & 0.80 \\
\hline 1 & 0.004 & 0.0020 & $\mathrm{TI}$ & $<0.0005$ & $<0.0002$ \\
\hline $\ln$ & $<0.001$ & $<0.0001$ & Tm & $<0.0005$ & $<0.0002$ \\
\hline Ir & r 0.0006 & $<0.0001$ & $u$ & 0. 080 & 0.015 \\
\hline$k$ & 3.8 & Matrix & $v$ & 0.00 & 0.003 \\
\hline La & 0.025 & 0.006 & w & 0.0060 & 0.002n \\
\hline Lu & $<0.0005$ & $<0.0002$ & Y & 0.01 & 0.002 \\
\hline $\mathrm{Mg}$ & 3.n & 0.45 & $Y B$ & $<0.0005$ & $=0.0007$ \\
\hline \multirow[t]{2}{*}{$M n$} & 0.19 & 0.07 & $\mathrm{Zn}$ & 0.44 & 0.15 \\
\hline & & & $\mathrm{Zr}$ & 0,06 & 0.01 \\
\hline
\end{tabular}

(1) Sludge solids were filtered and oven dried at $80^{\circ} \mathrm{C}$ prior to analysis.

(2) Sludge solids were filtered, washed with distilled water, and oven dried at $80^{\circ} \mathrm{C}$ prior to analysis. (3) Added conduciur. 


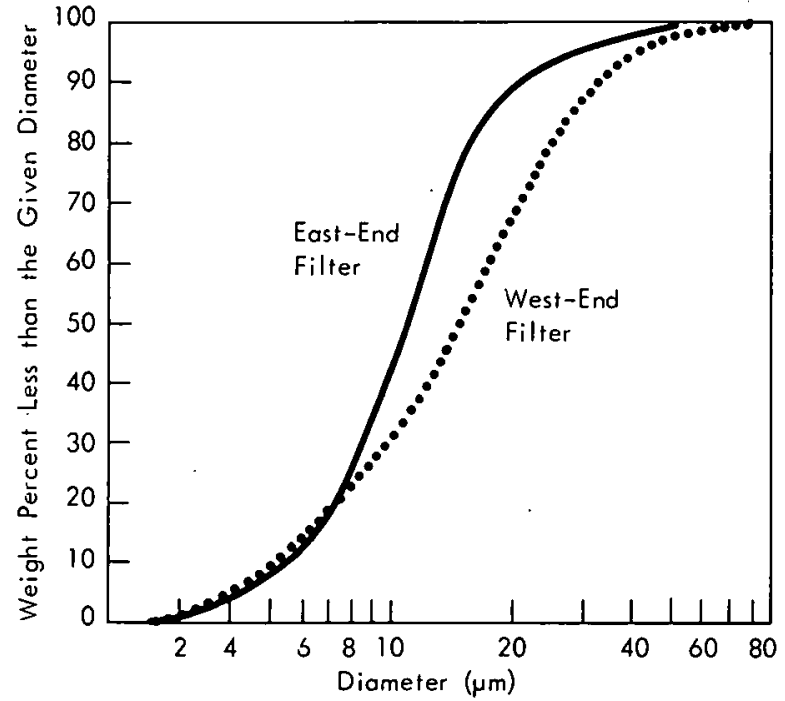

Figure 15. PARTICLE-SIZE DISTRIBUTION OF SUSPENDED SOLIDS REMOVED BY SIDESTREAM SAND FILTERS IN TWO Y-12 COOLING-WATER SYSTEMS. the tubes, channels, and floating heads of the heat exchangers. When such solids deposit out and lodge on metallic surfaces, especially at relatively low velocity portions of the cooling water system, there is also the danger of the development of corrosion cells and severe localized pitting. Also, the presence of considerable suspended solids in the recirculating cooling water makes it more difficult for the waterinhibiting treatment being applied to the system to be effective for preventing corrosion, inasmuch as a considerable amount of the dissolved inhibitor (eg, phosphate or chromate) would be lost in the blowdown by adsorption on the solids.

According to Hayes, ${ }^{(4)}$ the credits found to exist for reducing the suspended solids content in a 30,000-gpm-circulating-rate cooling-water system were: (1) a reduction of cooling tower chlorine usage that amounts to a savings of $\$ 250$ per year, (2) a reduction of the prorated cooling tower basin cleaning cost of $\$ 1,000$ per year, and (3) an improvement in the condenser heat transfer rate, resulting in a $\$ 30,000$ per year utility savings. After approximately one year, the sidestream filters have provided satisfactory and trouble-free operation, and it is planned to install. additional sidestream filters in other cooling water systems at the Plant. 


\section{REFERENCES}

(1) Schmitt, C. R.; Survey of the Fly-Ash Disposal System at the Oak Ridge Y-12 Plant, Y-1713; Union Carbide Corporation-Nuclear Division, Oak Ridge Y-12 Plant, Oak Ridge, Tennessee; April 20, 1970.

(2) Water Quality and Treatment, AWWA Manual, 2nd Edition; American Water Works Association, New York, New York (1960).

(3) "Automatic Gravity Filter Operates Without Valves," Public Works (1961).

(4) Hayes, J. W., Jr; Current Practice in Sidestream Filtration for Cooling Towers; Cooling Tower Institute Convention, Houston, Texas; January 23, 1967. 
DISTRIBUTION

Atomic Energy Commission - ORO

Hickman, H. D.

Zachry, D. S., Jr

Oak Ridge Gaseous Diffusion Plant

Patton, F. S.

Wilcox, W. J., Jr

Winkel, R. A.

Oak Ridge National Laboratory

Bender, $M$.

Oak Ridge Y.12 Plant

Burditt, R. B.

Burkhart, L. E.

Denny, A. (2)

Foulk, D. L.

Gary, W. E.

Jones, F. W.

Jordan, R. G.

Keith, Alvin

Kite, H. T.

Lundin, M. I.

Marrow, G. B.

McLendon, J. D.

Mitchel, G. W.

Morehead, J. $\Gamma$.

Napier, J. M.

Parsons, J. A.

Pokela, W. U.

Sanders, M.

Schabot, R. E.

Schmitt, C. R. (10)

Schreyer, J. M.

Smith, H. F., Jr

Smith, R. D.
Speas, I. G.

Strohecker, J. W.

Tench, F. M.

Tronolone, N. J.

Trotter, T. C.

Weathersby, W. E. (3)

Wilson, T. C.

Yaggi, W. J.

Y-12 Central Files (5)

$Y-12$ Central Files (master copy)

$Y-12$ Central Files (route)

Y-12 Central Files (Y-12RC)

Paducah Gaseous Diffusion Plant

Levin, R. W.

Merriman, J. R.

In addition, this report is distributed in accordance with the category UC-38, Engineering and Equipment, as given in the USAEC Standard Distribution Lists for Unclassified Scientific and Technical Reports, TID-4500. 